\title{
Hélène Jaccomard, Le fabuleux destin d'Amélie Nothomb
}

\section{Sophie Miller}

\section{(2) OpenEdition}

10 Journals

\section{Édition électronique}

URL : https://journals.openedition.org/studifrancesi/41312

DOI : 10.4000/studifrancesi.41312

ISSN : 2421-5856

Éditeur

Rosenberg \& Sellier

\section{Édition imprimée}

Date de publication : 1 juillet 2004

Pagination : 225-226

ISSN : 0039-2944

\section{Référence électronique}

Sophie Miller, «Hélène Jaccomard, Le fabuleux destin d'Amélie Nothomb », Studi Francesi [En ligne], 142 (XLVIII | I) | 2004, mis en ligne le 30 novembre 2015, consulté le 09 septembre 2021. URL : http:// journals.openedition.org/studifrancesi/41312 ; DOI : https://doi.org/10.4000/studifrancesi.41312

Ce document a été généré automatiquement le 9 septembre 2021.

\section{(c) (i) (9)}

Studi Francesi è distribuita con Licenza Creative Commons Attribuzione - Non commerciale - Non opere derivate 4.0 Internazionale. 


\title{
Hélène Jaccomard, Le fabuleux destin d'Amélie Nothomb
}

\author{
Sophie Miller
}

\section{RÉFÉRENCE}

HÉLÈNE JACCOMARD, Le fabuleux destin d'Amélie Nothomb, «L'Esprit Créateur», vol. XLII, 4, hiver 2002, pp. 45-57.

Dans son article, Hélène Jaccomard prend comme porte d'entrée le cinéma d'une vie, pour introduire l'écriture d'une vie, avec un clin d'œil malicieux au Fabuleux destin d'Amélie Poulain qui devient Le fabuleux destin d'Amélie Nothomb. Le lecteur est amené à approcher l'œuvre autobiographique d'Amélie Nothomb: Le Sabotage amoureux (1993), Stupeur et tremblements (1999), Métaphysique des tubes (2000), qui représentent trois tranches de vie différentes, respectivement l'enfance de cinq à huit ans, l'année des vingt-deux ans, les trois premières années de l'existence. «Fabuleux destin» car il s'agit d'après le critique d'un «conte philosophique», et l'A. tentera de démontrer l'originalité de leur auteur. À travers une subtile analyse, elle révèle la singularité de son écriture, par un parallèle entre l'autobiographie traditionnelle, ses poncifs et les trois textes autobiographiques. L'A. parcourt l'autofiction qu'elle résume en quelques mots comme «le raccourci entre le berceau et la bibliothèque», elle aborde ses traits marquants, en mêlant les divers textes. Elle évoque un contrat de lecture «provocateur et ludique»: «Une affirmation aussi énorme - je me souviens de tout - n'a aucune chance d'être crue par quiconque. Cela n'a pas d'importance. S'agissant d'un énoncé aussi invérifiable, je vois moins que jamais l'intérêt d'être crédible». Elle nous fait remarquer le lien étroit entre métaphysique et enfance, entre Genèse et genèse, dans l'image d'un bébé qui se prend pour Dieu.

2 L'A. nous dépeint l'autobiographie de Nothomb comme un texte dépourvu de psychologie mais pas de philosophie et encore moins d'humour. Elle s'arrête et insiste particulièrement sur le rôle important de l'enfant, "sans origines comme Dieu», sur 
l'univers égocentrique, dans lequel il évolue, tient une place divine, et, où la présence parentale est effacée. L'éducation à l'amour fait également partie des enjeux majeurs soulevés avec celui de la découverte de la sexualité, de l'homosexualité. Au-delà, elle aborde également un thème essentiel: l'identité culturelle et elle définit Nothomb de " personnage hybride». Elle s'attarde enfin sur la venue à la création littéraire dans l'autobiographie et le jeu complexe de la parole et de la nomination, en écrivant, «Nothomb nomme le monde». Trois contes autobiographiques nous sont donc présentés tout au long de l'article, la philosophie d'une vie où l'enfance est mythifiée et écrite avec humour. 